\title{
The Family Influence on Business: Czech Family Companies
}

\author{
Pavla Srbová ${ }^{1}$, and Mária Režňáková ${ }^{1, *}$ \\ ${ }^{1}$ Brno University of Technology, Faculty of Business and Management, Department of Finance, \\ Kolejní 2906/4, 61200 Brno-Královo Pole, Czech Republic
}

\begin{abstract}
.
Research background: Family businesses represent a combination of family and business aspects. Typically, a family is the majority owner and its members are top managers of the firm. The company name often contains the names of family members, i.e. they are publicly known. The family thereby gains recognition through the business operations of its firm, such as socially responsible business practices, and may also be considered a good employer. These aspects constitute its socioemotional wealth (SEW). Family business owners may consider the SEW to be of greater importance than typical corporate management, and this may be a reason for the lower profitability of family businesses.

The purpose of the article: The aim of this article is to describe selected factors influencing SEW and to verify their significance on data on Czech family companies.

Methods: The research was based on qualitative and quantitative data obtained by a questionnaire survey. Descriptive and statistical methods were used to analyse the formulated assumptions.

Findings \& value added: Most Czech family companies are run by the first or second generation of family owners. Since they consider their control and influence on their company to be extremely important, family owners do not typically consider the entry of non-family investors into the ownership structure. The assumption that family companies have a low level of indebtedness was not confirmed. The ownership of the company consists of one family, which usually keeps a $100 \%$ share. The family has at least one member in the top management. The founder of the company is typically the father. The family prefers to transfer the business to family members; firstly its management, then its ownership.
\end{abstract}

Keywords: family business; family influence; socioemotional wealth; Czech Republic

JEL Classification: D22; G32; L21; L26

\footnotetext{
* Corresponding author: reznakova@fbm.vutbr.cz
} 


\section{Introduction}

The interaction between family and business gives rise to a unique organisational entity the family firm - that reflects the way in which the family understands business. The family generally identifies with the business and its reputation is important to it. This expresses itself in a proactive attitude towards stakeholders [6]. The engagement of stakeholders in decision-making is one way of reinforcing mutual trust and obtaining agreement on the direction in which the business is headed and its management. These activities may be placed in doubt by shareholders due to the difficulty of demonstrating the positive influence of this approach on financial performance, for which reason the given approach is applied primarily in a family business in which the manager (generally a member of the family) is able to defend lower company returns for the reason of social orientation.

This article is devoted to family firms in the Czech Republic, which in the majority of cases have only a short history. Attention has been devoted to them in recent years in connection with the ongoing first intergenerational changeover. A definition of the family business was approved by the government of the Czech Republic last year (2019). This year, the Association of Small and Medium-sized Enterprises of the Czech Republic subsequently launched a public register of family firms, to which family firms can register voluntarily. To date, this database contains around 300 family firms, which is a low figure in comparison with the estimates of the total numbers (according to the federation of European Family Businesses, 87 \% of all businesses are business of a family type). In view of their short history, most of the family firms in the Czech Republic are small or mediumsized businesses, for which reason it can be assumed that a proactive approach to stakeholders is extremely important to these businesses for reasons associated with building their image and reputation through non-economic objectives. The aim of this article is to describe selected factors that support the attainment of non-economic objectives and to verify their existence in Czech family firms.

Our research is based on the assumption that family firms are associated with the pursuit of non-economic objectives that express themselves in the existence of socioemotional wealth. The concept of socioemotional wealth (SEW) is characterised as the non-financial aspects associated with a family business that serve to satisfy the needs of the family, such as its identity and influence and the preservation of dynasty [7]. Any decline in this SEW is generally seen as a great loss. To ensure that such a loss does not occur, the owners of these businesses are willing to take on greater risk, even the kind of risk that might threaten the very survival of the business itself.

SEW is a unique characteristic of family businesses (the most important factor) that differentiates family firms from non-family firms [3]. Other authors consider SEW a driver of family firm behaviour [15]. In this article, we focus for this reason on describing factors supporting the existence of SEW and their identification in Czech family firms.

Our research is based on the assumption that the aim of a family business is to achieve economic and non-economic objectives arising from the specific features of family business. These non-financial aspects form the socioemotional wealth (SEW) of a family firm.

There have been various approaches to the definition of SEW [11]. The authors define SEW as the non-financial value of the firm brought to the business by the family (what is in connection with the studies [3,1 and 16]). The existence of SEW is a consequence of the importance of the non-economic objectives of the business and leads to the fulfilment of the main goal of the family business, which is its long-term sustainability. SEW is considered to be the most important factor differentiating these concerns from ordinary businesses [3]. They specified five categories comprising SEW on the basis of their review of the literature: family control and influence, the identification of family members with the 
business, binding social ties, the emotional attachment of the members of the family, and the renewal of family links with the business through dynastic succession.

\subsection{Family control and influence}

For a family firm to be sustainable in the long term, it is important for the given family to maintain its influence within it, i.e. for it to retain its majority ownership or exercise the majority of voting rights. The family's influence on the business is affected by its share in strategic decisions. A greater degree of control is exercised if a member of the family is the managing director or chair of the administrative board and if it appoints the members of the top management team (TMT) [3]. Zona states that non-family directors are generally more qualified and more professional, though a member of the family in the position of director is of assistance in effective decision-making [17]. He claims that family directors are averse to risk, plan for the long term and fear the loss of SEW.

Not all family firms behave like family businesses. Some authors have been considered the question why certain families place greater emphasis on SEW [5]. In their opinion, identification with the business is important for an emphasis to be placed on non-financial objectives. This identification is associated with connecting control and influence in the company with social connections and the dynamics of family relationships. This points to the importance of managing family and company relations with the aim of supporting the identification of the family with the business. Based on their research conducted among Spanish private family firms, the authors found that a differing emphasis on non-financial objectives is dependent on the level of engagement of members of the family in the family business. Their research focused on identification with the business as a key factor in nonfinancial objectives. This may explain why there are differences between family firms and why some of them tend to behave more like non-family concerns. Their results show that the effect of identification with non-financial objectives is greater in businesses in which the majority of the TMT is made up of family members, i.e. the greater the level of participation of the family in the company management, the more important the role played by non-financial objectives.

A family is less willing to employ non-family members in managerial positions if SEW is important to the family firm [15]. Nevertheless, the willingness to employ non-family members grows alongside the growth of the business, the introduction of innovation and internationalisation. The emphasis on SEW can also be expected to give way to financial objectives when the firm belongs to later generations. The reason for this is the fact that its managers are not so strongly emotionally connected to the concern [14]. The identification of family members with the firm and the renewal of family bonds through dynastic succession exert a negative and significant impact on financial performance [12].

In addition to the preservation of ownership and managerial control over the concern, the non-financial objectives of the family also include keeping the ownership of the concern in the family, i.e. its succession within the family [4].

It can be deduced from this that if a company places an emphasis on SEW, then $a$ member of the family holds the position of director and that the majority of the TMT is made up of members of the family in a family firm. The family usually holds a $100 \%$ share and plans to pass it on to other members of the family.

\subsection{The indebtedness of family firms}

Debt financing is an appropriate way of financing the growth of a business as it is available more rapidly (and as a rule more simply) than the acquisition of own resources. It goes without saying that any disproportionate increase in the level of debt increases the risk of 
the transfer of ownership and control of the company to creditors should the company fail, i.e. be unable to pay its liabilities. The loss of control over the company is undesirable to the owners of company firms as they build their company for future generations and the reputation of the family is important to them. According to the authors Machek \& Hnilica, owners of family firms are more averse to the risk of indebtedness and make less use of debt financing than non-family concerns [9]. They reached this conclusion on the basis of a study conducted on a sample of medium and large Czech concerns. Greater business risk can be said to be compensated for by lower financial risk.

The level of indebtedness depends on the dispersion of ownership among family members [2]. This assertion is based on data on private Italian manufacturing family firms (unlisted small and medium-sized firms), i.e. on the characteristics of concerns similar to concerns operating in the Czech Republic. This dependence can be expressed by an inverted $U$ shape, with this effect moderated by generation. It was found that the level of indebtedness is lower in the first and second generation of owners under the assumption of concentrated ownership in the hands of a few members of the family, subsequently increases with the dispersion of ownership among members of the family, and then falls again as dispersion of family ownership reaches higher levels. This effect no longer applies in the third generation as the importance of SEW falls, while the opposite effect appears in further generations when the SEW is not so important.

As has already been mentioned, the level of indebtedness is derived from the importance of SEW to the given family. If there is a non-family member in the position of CEO, the company will take more entrepreneurial risk [8]. On the other hand, the authors of this study found that if a firm has an outside CEO, then such a company makes use of less debt than if there is a family member in the position of CEO. This study is concerned exclusively with family firms, and their finding does not, therefore, deny the possibility that such concerns are less indebted. The effect of an outside CEO on debt and risk-taking decreases when the board of family directors has stronger control over the outside CEO. Marszalek came to the conclusion that listed family firms in Central and Eastern Europe have a conservative financing policy, i.e. they are less indebted and have greater liquidity [10]. This effect is particularly evident in services and the construction industry. Other studies can, however, also be found whose authors have reached different views, and an overview of these is provided by, for example see [13]. It can be seen from this overview that no effect of the family on the level of indebtedness of the company has, as yet, been proven conclusively in the literature. If it is important to the family to maintain control, if it is averse to the risk of loss of control over the company and if non-financial objectives are important to it, then a higher preference for internally generated funds rather than external sources prevails within it. The family prefers debt to the entry of another investor (an increase of external equity funding) only in a situation in which it wants to reduce the risk of a loss of control over the company [2].

The conclusion can be deduced from the above that if a family firm places the emphasis on SEW, then the family firm has a low level of indebtedness and is unwilling to accept the entry of external investors.

\section{Methodology}

Our research aimed to determine whether the characteristics of family firms discussed in the foreign literature also apply to such firms in the Czech Republic. Descriptive statistics, first and foremost statistics of frequency, were used for the analysis of the data obtained. The reason for this is the size of the sample (57 companies). The following assumptions formulated about the functioning of family firms were investigated: 
1. The majority of family firms in the Czech Republic are managed and owned by their founders.

2. A member of the family holds the position of director and the majority of the TMT is made up of family members in family firms.

3. The family generally holds a $100 \%$ share and plans to pass the concern on to members of the family.

4. Family firms have a low level of indebtedness and are unwilling to accept the entry of external investors.

The given assumptions were checked on the basis of a questionnaire survey among owners of family firms. The following questions (in addition to questions about the legal form of business, branch of business, etc.) were placed by the questionnaire:

- Which generation owns the firm? Which generation runs the firm?

- Who was the founder of the firm (father, mother, etc.)? State the current share in the ownership of the firm held by the family.

- Would you be willing to accept the entry of an investor who is not a member of the family?

- If you are willing to accept the entry of a non-family investor, what share would you give up in its favour?

- For what reason would you be willing to accept the entry of a non-family investor?

- $\quad$ Are you planning to pass the management of the firm on to family members in the future? If not, what are your plans for the firm? Are you planning to continue to work at the firm (and in what position) after passing it on?

- How many people make up the management of the firm? How many family members hold positions in the management of the firm?

Data on the indebtedness of family firms was drawn from their financial statements, and the following questions were investigated: Is the indebtedness of family firms lower than the branch average? Do these firms make less use of bank credits than the branch average? Accounting data was obtained on 47 of the 57 analysed companies.

A business entity in which one family has an absolute majority of the number of partners or exercises a majority of voting rights is considered a family firm. At least one member of the given family is a member of the statutory body of the company. At least two members of the given family must be engaged in the company for it to be considered a family firm.

Our research sample includes 57 small and medium-sized private Czech family companies. These are 48 limited liability companies, 8 joint-stock companies and 1 selfemployed person. The investigated companies operate in this branches according CZNACE CODE: agriculture, forestry and fishing, A - 1,75\%, manufacturing, C - 49,12\%, construction, $\mathrm{F}-10,53 \%$, wholesale and retail trade, $\mathrm{G}-12,28 \%$, accommodation and food service, I - 1,75 \%, information and communication, $\mathrm{J}-1,75 \%$, real estate, $\mathrm{L}-1,75 \%$, professional, scientific and technical activities, $\mathrm{M}-3,51 \%$, administrative and support service $\mathrm{N}-7,02 \%$, education, $\mathrm{P}-3,51 \%$, arts, entertainment and recreation, $\mathrm{R}-1,75 \%$, other service $\mathrm{S}-5,26 \%$.

\section{Results}

The research indicated that Czech family firms are owned and managed predominantly by the first generation of the family. See Table 1 for details. 
Table 1. Generations of business owners and managers, drawn up by the authors.

\begin{tabular}{|c|c|c|c|c|c|}
\hline \multirow{2}{*}{$\begin{array}{c}\text { Generation of } \\
\text { owners }\end{array}$} & \multicolumn{4}{|c|}{ Generation of managers } & Total \\
\cline { 2 - 6 } & First & First \& second & Second & Other & \\
\hline First & 26 & 6 & 6 & 0 & 38 \\
\hline First \& second & 0 & 1 & 1 & 0 & 2 \\
\hline Second & 0 & 3 & 10 & 1 & 14 \\
\hline Other & 0 & 0 & 1 & 2 & 3 \\
\hline Total & 26 & 10 & 18 & 3 & 57 \\
\hline
\end{tabular}

The reason for this situation is the short history of family business in the Czech Republic that makes it impossible to investigate changes in the behaviour of family entrepreneurs in different generations. $67 \%$ of the companies analysed are owned by the first generation, which also manages the company in $46 \%$ of cases. Some of these companies have, however, already been passed on to the second generation. These are mostly companies founded in the first half of the nineteen nineties. The research also shows that the management of the company is transferred first, and ownership only later. These companies are often managed by the generation of founders and their successors together. The analysed sample also shows that $28 \%$ of companies are owned by the second generation or by the first and second generations together, while $49 \%$ of companies are managed by these generations. A company owned and managed by the fourth generation (this company was returned to the family during restitution) and a company owned by the second generation but managed by the third generation fall in the category other.

Table 2. The share of the family in the company, drawn up by the authors.

\begin{tabular}{|c|c|c|c|c|}
\hline Share of the family in the company & $<75 \%$ & $75-99.9 \%$ & $100 \%$ & total \\
\hline \multicolumn{2}{|c|}{ Number of cases } & 4 & 7 & 46 \\
\hline $\begin{array}{c}\text { Members of the family in the company } \\
\text { management }\end{array}$ & $\leq 50$ & $>50 \%$ & $100 \%$ & total \\
\hline \begin{tabular}{c} 
Number of cases \\
\hline
\end{tabular} & 12 & 14 & 31 & 57 \\
\hline
\end{tabular}

The majority of families in the analysed sample own $100 \%$ of the company (81\% of companies), while just 7 families own $75-100 \%$ and just 4 families hold a share of less than $75 \%$ of the ownership. It cannot be determined from the data whether the size of the share is influenced by the generation that owns the company. There is a lower proportion of ownership by a single family in the construction industry. This conclusion cannot, however, be applied universally, as only 6 of the companies in the research were engaged in this branch.

Members of the family hold a majority in the management of family firms $(79 \%$ of cases); in $54 \%$ of cases there are only members of the family in the management. The large proportion of members of a single family in the management can be accounted for by the fact that family business is characterised by an unwillingness on the part of the family to accept external managers. In just one company, which has already been passed on to the 
second generation, is the management comprised of just a single person who is not a member of the company, though the family holds a $100 \%$ share in this company.

Table 3. Willingness to accept a non-family investor and plans to pass the firm on to family members, drawn up by the authors.

\begin{tabular}{|c|c|c|c|}
\hline \multirow{2}{*}{$\begin{array}{c}\text { To accept the entry of a non- } \\
\text { family investor }\end{array}$} & \multicolumn{2}{|c|}{ To pass the firm on to family members } & \multirow{2}{*}{ Total } \\
\cline { 2 - 3 } & No & Yes & \\
\hline No & 7 & 27 & 34 \\
\hline Yes & 5 & 18 & 23 \\
\hline Total & 12 & 45 & 57 \\
\hline
\end{tabular}

$79 \%$ of all respondents (45 of 57 companies) plan to pass the company on to family members in the future. Another owner said that he is not planning to pass it on to family members, though he would like to put it in a trust fund to be administered by the family. Four owners stated that they are not planning to pass the company on to family members, while stating that they do not, as yet, have any plans regarding the future of their company. This indicates that preservation of the family nature of the business is a possibility for $88 \%$ of current owners (50 companies).

The remaining seven owners stated that they wish to sell their company. Three of these have, however, decided to stay on in the company as independent consultants following its sale.

The conclusion can be drawn from the above that only four owners have decided to sell their family firm and no longer continue to work for it. As the reason for this decision, one of them stated that he is selling the company "for the development of the company, where everyone has a lawyer, is bending the laws in his favour with no moral grounds or causing all kinds of factual damage". Stating reasons was entirely up to the owners. A possible reason for sale, in addition to disputes within the family, may be the absence of a possible successor who could take over the company.

Only $60 \%$ of families ( 34 companies) are unwilling to accept the entry of a non-family investor into the company. The other owners are willing to accept the entry of an investor to gain know-how, additional financial sources or new contacts

Table 4. External funding comparison of family firms and the branch average (in the period 20142018), drawn up from questionnaires and Ministry of Industry and Trade data.

\begin{tabular}{|l|c|c|c|c|}
\hline \multirow{2}{*}{\multicolumn{2}{|c|}{ CZ-NACE }} & \multicolumn{2}{|c|}{ Total liabilities/total assets } & \multicolumn{2}{c|}{ Bank credits/total assets } \\
\cline { 2 - 5 } & Family firms & Branch average & Family firms & Branch average \\
\hline A: agriculture, forestry etc. & $28 \%$ & $9 \%$ & $7 \%$ & $3 \%$ \\
\hline C: manufacturing & $47 \%$ & $43 \%$ & $20 \%$ & $9 \%$ \\
\hline F: construction & $92 \%$ & $48 \%$ & $20 \%$ & $5 \%$ \\
\hline G-N*: selected services & $66 \%$ & $57 \%$ & $16 \%$ & $18 \%$ \\
\hline P-S*: other services & $56 \%$ & $55 \%$ & $14 \%$ & $19 \%$ \\
\hline
\end{tabular}

*A summary description of which services belong to a given category is given in the Methodology 
. In response to the question as to whether the owner is willing to accept the entry of an external investor, five owners stated that they are willing to part with a share of as much as $100 \%$. Four of these owners are, however, so far planning to pass their company on to their descendants.

The proportion of total liabilities to total assets is higher in the selected family firms than the average value for the given sector in the period 2014 to 2018. This higher value is also the result of the frequent negative equity in family firms. The situation is similar in the use of bank credits. Over the last five years, the share of bank credits is higher in family firms than the average value in the given branch. The situation is opposite in the services sector, with the proportion of bank credits to total assets lower in the case of family firms. The largest number of companies are in the manufacturing sector, in which the average indebtedness of family firms over five years (2014-2018) is 4 percentage points higher than the branch average. Family firms in this branch also have a significantly higher proportion of bank credits to total assets (11 percentage points higher). The results show that the assertion of lower indebtedness in family firms does not hold true of the majority of them. In this analysis it is, of course, necessary to consider the fact that data on just 47 family companies was used (accounting data was not available for 10 family firms and the owners of these companies were not willing to provide it).

Table 5. Who is the founder of the company, drawn up by the authors.

\begin{tabular}{|c|c|c|}
\hline Founder of the company & Frequency & Relative frequency \\
\hline Both partners & 10 & $17.54 \%$ \\
\hline Father & 38 & $66.67 \%$ \\
\hline Mather & 1 & $1.75 \%$ \\
\hline Non-family members & 5 & $8.77 \%$ \\
\hline Not identified & 3 & $5.26 \%$ \\
\hline Total & 57 & $100 \%$ \\
\hline
\end{tabular}

Family firms are characterised by the fact that they are founded by the father of the family $(67 \%)$. Some of these companies are, however, founded by both partners $(18 \%)$. The foundation of a family firm by the mother of the family is unusual, and was the case in just one company in the services sector in the given sample. Some companies become family firms during the course of their existence (see Table 5).

\section{Discussion}

Our review of the literature and our own research show that the creation and maintenance of SEW is important to family firms. The creation of SEW is influenced by the emphasis placed by the family on the non-financial objectives of their business and on the long-term prospects of their family firm. We focused on investigating the existence of SEW in our research. The responses given by the owners of 57 family firms showed that only four current owners want to sell their business and abandon it entirely. Although some others are now considering a sale, they want to continue in the company as independent consultants. It can be judged from this that the owners of family firms have an interest in maintaining their business over the long term. 
For family firms creating SEW is typical that the family identifies itself with the business [5]. This is achieved, first and foremost, by the engagement of members of the family in the management of the company. Any decline in the level of engagement of the family in the business (a fall in the family's emotional connection to the business) leads to a fall in the importance of SEW. If the family is planning to sell its firm, it can be expected to take a different approach to its management than if the plan is to pass the business on to future generations. Our research confirmed the assumption that a member of the family generally the founder who plans to pass the business on to his or her descendants - holds the position of director in a family firm. In the majority of companies (more than threequarters of cases), members of the family form a majority in the management of the company. What's more, the majority of family firms are owned and managed by their founder, who is usually the father of the family; both partners are involved in only a few cases. In more than half of the companies, the members of the top management are exclusively members of the family. Owners fear the loss of control over the company and are therefore unwilling to accept external managers.

It is also true of the owners of family firms that they are generally unwilling to accept the entry of external investors (investors from outside the family). They are afraid of the risk of losing control over the company [2]. The family is willing to give its company up entirely in favour of external investors only in the case of problematic family relations or when the family has no suitable successor. The data obtained does not unequivocally point to an unwillingness to accept non-family investors, with $40 \%$ of respondents considering this possibility. They are willing to accept the entry of an investor in order to obtain knowhow, additional financial sources or new contacts. $60 \%$ of owners of family firms are unwilling to accept an external investor. 46 of the 57 family firms included in this research are owned by a single family (the family holds a $100 \%$ share).

Family firms are less likely to become indebted according to the conclusions of a previous piece of research conducted on a sample of medium and large companies in the Czech Republic [9]. Our research did not confirm this finding. The average degree of indebtedness in the companies we analysed is higher than the branch average in the majority of fields (according to data from the Ministry of Industry and Trade). The opposite is true only in the services sector, i.e. the proportion of bank credits to total assets is lower than the branch average in the case of family firms. It goes without saying, however, that consideration must be paid here to the fact that our sample was comprised of 47 small and medium-sized family firms (accounting data was not obtained for 10 companies) whose financial situation is less stable than is the case for large concerns. Our findings confirm that the influence of family on the level of indebtedness of the concern has not, as yet, been unequivocally demonstrated [13]. It can, however, be stated that the responses of our respondents support the conclusions that the family prefers debt to the entry of a further investor [2].

\section{Conclusion}

Our research investigated the validity of the conclusions reached by previous pieces of research (particularly from abroad) that have considered the influence of family on business. According to the given pieces of research, the family has a fundamental influence on business and is expressed in the creation of socioemotional wealth. If a family is not interested in the long-term development of the business, this is expressed in a decline in socioemotional wealth. Our aim was, for this reason, to determine whether there are characteristics typical of the owners of family firms in the Czech Republic that support the creation of socioemotional wealth. 
We conducted our research on a sample of 57 small and medium-sized family firms. We found that more than a half of the family firms in our sample are owned by a single family that holds a $100 \%$ share. Of the businesses analysed, $67 \%$ are owned by the first generation of owners, and this generation also manages the company in $46 \%$ of cases. A member of family holds the position of director in the family firm and members of the family form the majority of the top management. The family is interested in the long-term development of the business and plans to pass the business on to members of the family - this is the case for $79 \%$ of family firms. The family is unwilling to accept the entry of external investors due to the fear of losing control over the company.

The conclusions of our research are not universally valid in view of the small sample. In a further piece of research we will focus on checking the validity of our theoretical assumptions on a larger data sample. In view of the fact that the majority of Czech family firms are in the hands of the first or second generation, it is not yet possible to examine the impact of the change of generation of owners on the business and the creation of socioemotional wealth.

This research has been carried out within the project "Family firms: Value drivers and value determination in the process of succession", ID Number TL02000434 co-financed by the Technology Agency of the Czech Republic.

\section{References}

1. Astrachan, J.H., Jaskiewicz, P. (2008). Emotional returns and emotional costs in privately held family businesses: Advancing traditional business valuation. Family Business Review, 21(2), 139-149.

2. Bacci, S., Cirillo, A., Mussolino, D., Terzani, S. (2018). The influence of family ownership dispersion on debt level in privately held firms. Small Business Economics, 51(3), 557-576.

3. Berrone, P., Cruz, C., Gomez-Mejia, L. R. (2012). Socioemotional Wealth in Family Firms: Theoretical Dimensions, Assessment Approaches, and Agenda for Future Research. Family Business Review, 25(3), 258-279.

4. Binz, C. A., Ferguson, K. E., Pieper, T. M., Astrachan, J. H. (2017). Family business goals, corporate citizenship behaviour and firm performance: disentangling the connections. International Journal of Management and Enterprise Development, 16(12), 34-56.

5. Cabrera-Suárez, M. K., Déniz-Déniz, M. D. L. C., Martín-Santana, J. D. (2014). The setting of non-financial goals in the family firm: The influence of family climate and identification. Journal of Family Business Strategy, 5(3), 289-299.

6. Cennamo, C., Berrone, P., Cruz, C., Gomez-Mejia, L. R. (2012). Socioemotional wealth and proactive stakeholder engagement: Why family-controlled firms care more about their stakeholders. Entrepreneurship Theory and Practice, 36(6), 1153-1173.

7. Gómez-Mejía, L. R., Haynes, K. T., Núñez-Nickel, M., Jacobson, K. J., MoyanoFuentes, J. (2007). Socioemotional wealth and business risks in family controlled firms: Evidence from Spanish olive oil mills. Administrative science quarterly, 52(1), 106-137.

8. Lardon, A., Deloof, M., Jorissen, A. (2017). Outside CEOs, board control and the financing policy of small privately held family firms. Journal of Family Business Strategy, 8(1), 29-41. 
9. Machek, O., Hnilica, J. (2014). Do family firms use less debt than other firms? Empirical evidence from the Czech medium and large companies. In F. Batzias, N. E. Mastorakis \& C. Guarnaccia, Recent Advances in Energy, Environment and Financial Planning: Proceedings of the 5th International Conference on Development, Energy, Environment and Economics (pp. 232-236). Italy: North Atlantic University Union.

10. Marszalek, J. (2018). Personal determinants of the family business capital structure Central and Eastern European analysis. In Proceedings of the 10th International scientific conference New challenges of economic and business development - 2018: productivity and economic growth (pp. 432-442). Riga: University of Latvia.

11. Martínez-Romero, M. J., Rojo-Ramírez, A. A. (2016). SEW: Looking for a definition and controversial issues. European Journal of Family Business, 6(1), 1-9.

12. Martínez-Romero, M. J., Martínez-Alonso, R., Casado-Belmonte, M. P. (2020). The influence of socio-emotional wealth on firm financial performance: evidence from small and medium privately held family businesses. International Journal of Entrepreneurship and Small Business, 40(1), 7-31.

13. Michiels, A., Molly, V. (2017). Financing decisions in family businesses: a review and suggestions for developing the field. Family Business Review, 30(4), 369-399.

14. Sciascia, S., Mazzola, P., Kellermanns, F.W. (2014). Family management and profitability in private family-owned firms: introducing generational stage and the socioemotional wealth perspective. Journal of Family Business Strategy, 5(2), 131 137.

15. Vandekerkhof, P., Steijvers, T., Hendriks, W., Voordeckers, W. (2015). The effect of organizational characteristics on the appointment of nonfamily managers in private family firms: The moderating role of socioemotional wealth. Family Business Review, 28(2), 104-122.

16. Zellweger, T.M., Astrachan, J. H. (2008). On the emotional value of owning a firm. Family Business Review, 21(4), 347-363.

17. Zona, F. (2016). CEO leadership and board decision processes in family-controlled firms: comparing family and non-family CEOs. Small Business Economics, 47(3), 735753. 